\title{
La Dolce Vita in Japan: The Effect of Bank Mergers on Corporate
} Governance

\author{
Heather Montgomery ${ }^{1} \&$ Yuki Takahashi ${ }^{2}$ \\ ${ }^{1}$ Sr. Associate Professor, Department of Business and Economics, International Christian University, Tokyo, Japan \\ ${ }^{2} \mathrm{PhD}$ Candidate, Department of Economics, State University of New York at Stony Brook, Stony Brook, NY, USA \\ Correspondence: Heather Montgomery, Department of Business and Economics, International Christian University, \\ 3-10-2 Osawa, Mitaka-shi, Tokyo 181-8585, Japan. Tel: 81-422-33-3277.
}

Received: October 30, 2015

Accepted: November 24, 2015

Online Published: December 21, 2015

doi:10.5430/ijfr.v7n1p57

URL: http://dx.doi.org/10.5430/ijfr.v7n1p57

\begin{abstract}
This study examines whether bank mergers change the relationship between market power and efficiency. Using two-stage least-squares instrumental variable estimation to address potential endogeneity between market power and efficiency, we confirm that market power is associated with higher profit efficiency. That analysis is then extended to examine how the relationship between market power and efficiency changes after bank mergers. The results are striking. The relationship between profit efficiency and market power becomes negative after banks merge. This effect is most significant for large and mega bank mergers, which experience significant increases in market power after merger. The increase in market power that accrues due to bank mergers does not lead bank managers to reap potential monopoly profits and boost efficiency. On the contrary, there is evidence that bank managers exploit their higher market power to pursue la dolche vita, or "the sweet life".
\end{abstract}

Keywords: bank, merger and acquisition, efficiency, monopoly power, mega merger, stochastic frontier, lerner index, Japan

"Even the most miserable life is better than a sheltered existence in an organized society where everything is calculated and perfected." Steiner, in Frederico Fellini's La Dolce Vita (The Sweet Life)

\section{Introduction}

On the day that Japan's Dai-Ichi Kangyo Bank (DKB), Fuji Bank and Industrial Bank of Japan (IBJ) merged into one of the world's largest banks, the new Mizuho Bank's ATMs stopped working due to a computer system failure, leaving depositors unable to withdraw money (Nihon Keizai Shimbun, 2002). That was just the first in a series of public management failures by newly-merged Japanese banks. The problems are usually attributed to difficulties integrating. There are reports of lingering rivalry among management of the former banks even today, more than a decade after merger. One solution has been the practice of "tasukigake-jinji" - periodically rotating important positions to managers from each pre-merger bank - raising new concerns about the quality of corporate governance in Japan's banks. Ito (2001), for example, argues that this practice has prevented merged banks from realizing potential merger gains. Those concerns are backed up by other studies in Japan which find that commercial bank mergers tend to reduce cost efficiency - where we might expect to find the most value created - and have no significant impact on the bottom line of profit efficiency (Note 1). However, the existing literature still leaves open the question of how banking sector consolidation affects efficiency, including the channel of market power. In this study, we examine how bank mergers affect the relationship between market power and efficiency.

Although the anecdotes above may not bring to mind the image of "the sweet life" for the CEOs involved, they are consistent with the so-called "quiet life" hypothesis named after Hicks (1935), who famously quipped that "The best of all monopoly profits is a quiet life" (p. 8). The hypothesis is articulated by Koetter, Kolari, and Spierdijk (2012) as the contention that "firms with market power prefer to operate inefficiently rather than reap all potential rents" (p. 462). Indeed, the hypothesis that market power leads to less efficient management is probably the underlying motivation behind many public policies such as anti-trust legislation and deregulation. Most academic economists 
agree that competitive markets should promote more efficient allocation of resources and empirical research tends to confirm that contention. For example, Bertrand and Mullainathan (2003) demonstrate that weakening anti-trust laws results in management consistent with the "quiet life" hypothesis.

This study tests the hypothesis that after merger, Japanese bank managers take advantage of their increased market power to enjoy "the sweet life" rather than enhancing efficiency to cut costs and boost revenue. With rigorous empirical techniques, the analysis here confirms that bank mergers increase market power, as we might expect. On average, there is a positive relationship between market power and efficiency, which at first seems to contradict the hypothesis. However there is also evidence that bank mergers change bank management practices, reversing that relationship. Large and "mega" bank mergers (post-merger total assets exceeding 10 or 80 trillion yen, respectively) in particular seem to give managers the option and incentive to pursue "the sweet life".

The rest of this study is organized as follows. The following section explains the empirical methodology and section 3 the results. Section 4 concludes.

\section{Empirical Methodology}

This section describes the details of our data and empirical methodology for estimating efficiency and market power.

\subsection{Data}

Table 1 reports the summary statistics of the data used in the analysis: 151 city, trust, long-term credit, regional and regional II banks' unconsolidated balance sheets and income statements for fiscal years 1996-2009 (Note 2). Balance sheet and income statement data are obtained from the Analysis of Financial Statements of All Banks published by the Japanese Bankers' Association. Since trust and long-term credit banks are included, items specific to those banks are included to accurately capture their activities.

Table 1. Descriptive statistics, 1996-2002

\begin{tabular}{lccccc}
\hline & Observations & Mean & $\begin{array}{c}\text { Standard } \\
\text { Deviation }\end{array}$ & Min & Max \\
\hline Outcome & & & & & \\
$\quad$ Profit ( $\pi)$ & 1,818 & 37,639 & 99,278 & $-160,269$ & $1,295,860$ \\
$\quad$ Cost (C) & 1,818 & 108,265 & 254,078 & 3,761 & $2,626,037$ \\
Outputs & & & & & \\
$\quad$ Total loans (y1) & 1,818 & $3,557,621$ & $7,830,012$ & 102,055 & $69,413,456$ \\
$\quad$ Total securities (y2) & 1,818 & $1,830,764$ & $5,307,649$ & 3 & $61,696,968$ \\
$\quad$ Trading income (y3) & 1,817 & 3,001 & 19,088 & 1 & 426,900 \\
Input prices & & & & & \\
$\quad$ Price of deposits (w1) & 1,818 & 0.003 & 0.003 & 0.0002 & 0.03 \\
$\quad \begin{array}{l}\text { Price of physical capital (w2) } \\
\text { Price of labor (w3) }\end{array}$ & 1,818 & 0.46 & 0.25 & 0.01 & 3.06 \\
Quasi-fixed input & 1,818 & 8.37 & 1.56 & 4.76 & 17.78 \\
$\quad$ Total equity (E) & 1,818 & 245,485 & 565,608 & $-214,505$ & 7318,250 \\
Normalizer & & & & & \\
$\quad$ Total assets (z) & 1,818 & $5,901,594$ & $14,625,437$ & 155,043 & $149,007,568$ \\
Risk variables & & & & & \\
$\quad$ Credit risk (NPL/L) (\%) & 1,818 & 5.66 & 4.13 & 0 & 73.32 \\
$\quad$ Liquidity risk (LA/TA) (\%) & 1,818 & 6.55 & 3.24 & 0 & 33.41 \\
$\quad$ Insolvency risk (Z-score) (\%) & 1,814 & 2,688 & 1,730 & -157 & 11,057 \\
Average Revenue & 1,818 & 0.03 & 0.01 & 0.01 & 0.11 \\
\hline P
\end{tabular}

Notes: Units are million yen (at 2000 price). The sample is 151 banks over 14 years with a total of 1,818 observations.

In Table 1, profits are net operating profits and costs are the sum of interest expenses, personnel expenses, non-personnel expenses and the amount of loan-loss provisions and write-offs. In defining inputs and outputs we employ the intermediation approach by which inputs - labor, physical capital and deposits - are used to produce earning assets. As shown in table 1, total loans (y1) and total securities (y2) are earning assets. The off-balance sheet 
portion of non-interest income, trading income (y3) is also included as a proxy for off-balance sheet activities. Three input prices are used: the price of deposits (w1), the price of physical capital (w2), and the price of labor (w3). Equity capital (z) is included as a standalone quasi-fixed input or netput. Total assets (q) is a normalizer. Of the three risk variables, the first, asset quality or credit risk is represented by the ratio of non-performing loans to total loans (NPL/L). Liquidity risk (LA/TA), is represented by the ratio of liquid asset to total assets. Insolvency risk, represented by the Z-score, is calculated as each individual bank's mean ROA plus mean equity to total assets divided by the standard deviation of total assets for each individual bank. Average revenue is ordinary income divided by total assets.

\subsection{Efficiency}

To estimate efficiency, we estimate the followng profit function:

$$
\begin{aligned}
n\left(\frac{\pi+\theta}{w_{3} q}\right)_{i, t}=\alpha_{0} & \\
& +\sum_{j=1}^{3} \alpha_{j} \ln \left(\frac{y_{j}}{q}\right)_{i, t}+\sum_{h=1}^{2} \beta_{h} \ln \left(\frac{w_{h}}{w_{3}}\right)_{i, t}+\eta_{1} \ln (z)_{i, t} \\
& +\frac{1}{2} \sum_{j=1}^{3} \sum_{k=1}^{3} \alpha_{j k} \ln \left(\frac{y_{j}}{q}\right)_{i, t} \ln \left(\frac{y_{k}}{q}\right)_{i, t} \\
& +\frac{1}{2} \sum_{h=1}^{2} \sum_{l=1}^{2} \beta_{h l} \ln \left(\frac{w_{h}}{w_{3}}\right)_{i, t} \ln \left(\frac{w_{l}}{w_{3}}\right)_{i, t}+\frac{1}{2} \eta_{11} \ln (z)_{i, t} \ln (z)_{i, t} \\
& +\sum_{j=1}^{3} \sum_{h=1}^{2} \gamma_{j h} \ln \left(\frac{y_{j}}{q}\right)_{i, t} \ln \left(\frac{w_{h}}{w_{3}}\right)_{i, t}+\sum_{j=1}^{3} \zeta_{j 1} \ln \left(\frac{y_{j}}{q}\right)_{i, t} \ln (z)_{i, t} \\
& +\sum_{h=1}^{2} \xi_{j 1} \ln \left(\frac{w_{h}}{w_{3}}\right)_{i, t} \ln (z)_{i, t}+\sum_{j=1}^{3}\left[\psi_{j} \cos x_{j}+\omega_{j} \sin x_{j}\right]_{i, t} \\
& +\sum_{j=1}^{3} \sum_{k=1}^{3}\left[\psi_{j k} \cos \left(x_{j}+x_{k}\right)+\omega_{j k} \sin \left(x_{j}+x_{k}\right)\right]_{i, t} \\
+ & \left(\frac{L A}{T A}\right)_{i, t}+\tau_{3} Z S \operatorname{sor} e_{i}+\tau_{4}\left(\frac{N P L}{L}\right)_{i, t} \ln (z)_{i, t}+\tau_{5}\left(\frac{L A}{T A}\right)_{i, t} \ln (z)_{i, t} \\
& +\tau_{6} Z S \operatorname{sor} e_{i} \ln (z)_{i, t}+\delta_{t} \Delta r_{t}^{J G B}+\rho_{i} I_{i}+v_{i, t}-u_{i, t} \\
+\tau_{1}\left(\frac{N P L}{L}\right)_{i, t} &
\end{aligned}
$$

In equation (1), subscripts $i$ and $t$ represent bank $i$ and time $t$, respectively. $\pi$ represents profit and $\theta$ represents the absolute value of the minimum profit $(\pi)$ over all banks in the sample - we add this constant because several observations report profit less than 0 but the log of a negative number is undefined. $q$ represents total assets, which we use as a normalizer. $z$ represents equity capital which is used as a netput. $y_{j}$ and $y_{k}$ represent the $j$ th and $k$ th output (total loans, total securities or trading income), respectively. $w_{h}$ represents the $h$ th input price (the price of deposits, price of physical capital or price of labor). $T_{t}$ is a time fixed effect which controls for macroeconomic factors such as interest rate risk, business cycle, etc., that affect all banks and $I_{i}$ is a bank-type fixed effect which controls for differences across different types of banks. Three risk variables - credit risk, liquidity risk and insolvency risk - are defined as the ratio of non-performing loans to total loans, the ratio of liquid assets to total assets and the bank z-score, respectively.

The trigonometric term, $x_{j}$ is the adjusted value of output $\ln \left(y_{j} / q\right)$ such that their interval is between 0 and $2 \pi$. $v_{i, t}$ represents random error term of bank $i$ in time $t . u_{i, t}$ represents the inefficiency of bank $i$ at time $t$, which is assumed to follow a half-normal distribution.

After estimating equation (1), including parameters $\alpha, \beta, \eta, \gamma, \zeta, \xi, \psi, \omega, \tau, \delta, \rho$, the efficiency of each bank can be isolated employing Battese and Coelli's (1988) point estimator.

\subsection{Measuring Market Power}

The Lerner Index is used as a measure of market power for each bank-year observation: the higher the index, the more market power the bank has. The Lerner Index is a proxy for the monopoly mark-up, and calculated as the 
difference between average revenue and marginal cost, expressed as a ratio of average revenue, or:

$$
\text { Lerner Index } x_{i, t}=\frac{A R_{i, t}-M C_{i, t}}{A R_{i, t}}
$$

Where $A R_{i, t}$ is average revenue of bank $i$ at time $t$, serving as a proxy of the output price set by the bank. $M C_{i, t}$ is marginal cost of bank $i$ at time $t$. Since each banks' marginal cost cannot be directly observed, it is estimated using the methodology of Fu, Lin, and Molyneux (2014). The first step is to estimate the following translog cost function using ordinary least squares:

$$
\begin{aligned}
\ln \left(\frac{C}{w_{2}}\right)_{i, t}=\alpha_{0} & +\alpha_{1} \ln (T A)_{i, t}+\beta_{1} \ln \left(\frac{w_{1}}{w_{2}}\right)_{i, t}+\frac{1}{2} \alpha_{11}\left(\ln (T A)_{i, t}\right)^{2}+\frac{1}{2} \beta_{11}\left(\ln \left(\frac{w_{1}}{w_{2}}\right)_{i, t}\right)^{2} \\
& +\gamma_{11} \ln (T A)_{i, t} \ln \left(\frac{w_{1}}{w_{2}}\right)_{i, t}+\delta_{1} \text { Trend }_{t}+\delta_{2} \text { Trend }_{t}^{2}+\delta_{3} \ln \left(\frac{w_{1}}{w_{2}}\right)_{i, t} \text { Trend }_{t} \\
& +\delta_{4} \ln (T A)_{i, t} \text { Trend }_{t}+\varepsilon_{i, t}
\end{aligned}
$$

In equation (3), subscripts $i$ and $t$ represent bank $i$ and time $t$, respectively. $C$ is total cost. $T A$ is total assets. $w_{1}$ is the price of deposits and $w_{2}$ is the price of labor and physical capital. Trend $t$ is a linear time trend and $\varepsilon$ is the error term.

Marginal cost is the derivative of total costs with respect to total assets:

$$
M C_{i, t}=\frac{\partial C_{i, t}}{\partial T A_{i, t}}=\frac{C_{i, t}}{T A_{i, t}}\left(\alpha_{1}+\alpha_{11} \ln (T A)_{i, t}+\gamma_{11} \ln \left(\frac{w_{1}}{w_{2}}\right)_{i, t}+\delta_{4} \text { Trend }_{t}\right)
$$

Plugging in coefficient estimates from equation (3) to equation (4) yields an empirical estimate of marginal cost, $\widehat{M C}_{i, t}$, which is used in equation (2) to calculate the Lerner Index, a measure of market power.

\section{Results: Mergers, Market Power and Efficiency}

This section discusses the results of our empirical analysis of (i) whether bank mergers actually increase market power (ii) whether increased market power is associated with higher or lower bank efficiency and (iii) whether merger events significantly change the relationship between market power and efficiency.

\subsection{Does M\&A Increase Market Power?}

The first step to disentangling the channel through which bank mergers affect efficiency is to confirm that, as we implicitly assume, bank mergers do indeed increase market power. Figure 1 plots the Lerner Index measure of market power around merger events for acquirer banks for large and mega-banks: those banks that have the most market power. Figure 1 illustrates that mergers that resulted in large (post-merger total assets of 10 trillion yen or more) or "mega" (post-merger total assets exceeding 80 trillion yen) banks do clearly tend to increase market power. As illustrated in Figure 2, the same is not true for mergers of banks which, even after the merger event, remain small or medium (total assets less than 10 trillion yen), so for the remaining analysis we focus on large and mega mergers. 


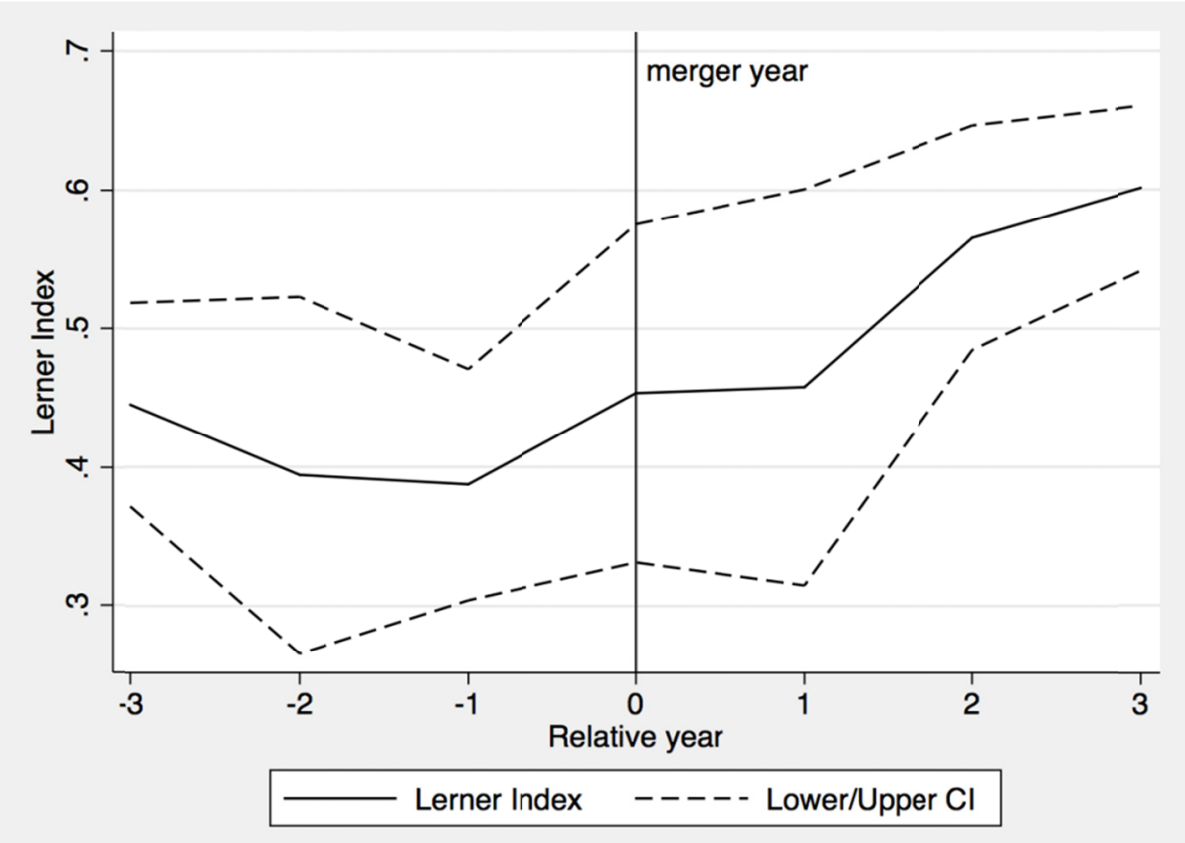

Figure 1. The change in market power around merger events - large and mega banks Note: dashed lines denote $95 \%$ confidence bands.

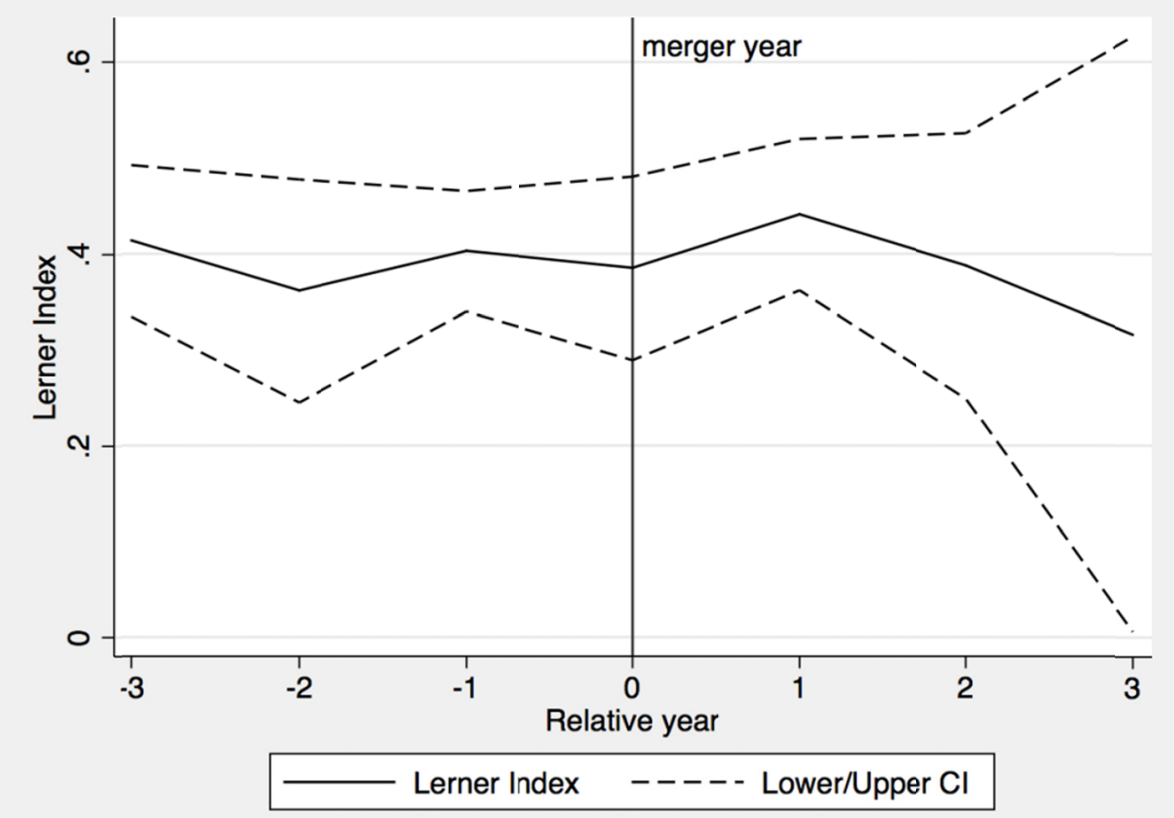

Figure 2. The change in market power around merger events - small and medium banks

Note: dashed lines denote $95 \%$ confidence bands.

\subsection{Does Increased Market Power Reduce Efficiency?}

Next we examine the effect of market power on efficiency. This suggests the following reduced form specification:

$$
\text { efficiency }_{i, t}=\alpha+\eta \text { Lerner }_{i, t}+\sum_{j=2}^{3} \beta_{j} M \& \text { Atatus }_{i, t}^{j}+\gamma \text { Target }_{i, t}+\sum_{k=2}^{4} \delta_{k} \text { Size }_{i, t}^{k}+\varepsilon_{i, t}
$$


Although OLS or median regression analysis of equation (5) can control for market power by including the Lerner Index, such analysis cannot provide unbiased estimates of the relationship between profit efficiency and market power because it seems likely that profit efficiency and mark-up (the numerator of Lerner Index) are simultaneously determined. If banks, for example, set their mark-up to the point that maximizes profit then we cannot identify the true relationship between profit efficiency and the Lerner Index without controlling in some way for the potential endogeneity between profit efficiency and market power. To address this potential simultaneity bias, we turn to instrumental variables.

Following the literature (Arellano \& Bond, 1991; Blundell \& Bond, 1998), we instrument for market power using lagged values of the Lerner Index. Test statistics indicate that our instruments work well. The F statistic in the first stage regression is large - well above 10 - for all specifications, suggesting that our instruments are relevant - well correlated with the potential endogenous variable, the Lerner Index. In addition, a high p-value the Sargan test suggests that our instruments are uncorrelated with the error term for all specifications.

The results of two-stage least-squares estimation of equation (5) using instrumental variables reported in columns 1-2 of Table 2 show that even using instrumental variables for the Lerner Index, banks with more market power, as indicated by a higher Lerner Index, tend to have higher profit efficiency. Thus, we have confirmed the following: mergers increase market power for banks entering into large and mega banks and higher market power is associated with higher profit efficiency. We next investigate the impact of bank mergers on this positive relationship between market power and efficiency.

Table 2. The relationship between market power and efficiency for large and mega banks - 2SLS-IV Instrumental Variable Regression

\begin{tabular}{|c|c|c|c|c|}
\hline & Profit efficiency & $\begin{array}{l}\text { Rank profit } \\
\text { efficiency }\end{array}$ & Cost efficiency & Rank cost efficiency \\
\hline \multirow[t]{2}{*}{ Lerner Index } & $0.24 * * *$ & $0.26 *$ & 0.02 & -0.18 \\
\hline & {$[0.064]$} & {$[0.145]$} & {$[0.049]$} & {$[0.155]$} \\
\hline \multirow[t]{2}{*}{ After M\&A } & $0.12 * *$ & $0.28 * *$ & -0.04 & -0.00 \\
\hline & [0.049] & {$[0.112]$} & {$[0.038]$} & {$[0.120]$} \\
\hline \multirow[t]{2}{*}{ Never M\&A } & $-0.09 * * *$ & -0.10 & 0.03 & 0.13 \\
\hline & {$[0.033]$} & {$[0.076]$} & {$[0.026]$} & {$[0.081]$} \\
\hline \multirow[t]{2}{*}{ Target } & $-0.10 * * *$ & $-0.15^{*}$ & 0.01 & 0.11 \\
\hline & {$[0.034]$} & {$[0.077]$} & {$[0.026]$} & {$[0.083]$} \\
\hline \multirow[t]{2}{*}{ Mega } & $-0.18 * * *$ & $-0.23 * * *$ & 0.02 & 0.14 \\
\hline & {$[0.038]$} & {$[0.086]$} & {$[0.029]$} & {$[0.092]$} \\
\hline \multirow[t]{2}{*}{ Large } & $-0.06 * * *$ & -0.05 & -0.02 & -0.01 \\
\hline & {$[0.020]$} & {$[0.046]$} & {$[0.016]$} & [0.049] \\
\hline \multirow[t]{2}{*}{ Small } & $0.04 * * *$ & $0.07 * * *$ & 0.00 & -0.00 \\
\hline & {$[0.008]$} & {$[0.018]$} & {$[0.006]$} & [0.019] \\
\hline \multirow[t]{2}{*}{ Constant } & $0.71 * * *$ & $0.48^{* * *}$ & $0.80^{* * *}$ & $0.47^{* * *}$ \\
\hline & {$[0.037]$} & {$[0.085]$} & {$[0.029]$} & {$[0.091]$} \\
\hline Observations & 1,286 & 1,286 & 1,286 & 1,286 \\
\hline Number of banks & 133 & 133 & 133 & 133 \\
\hline Number of years & 12 & 12 & 12 & 12 \\
\hline $\begin{array}{l}\text { F statistic for } \\
\text { instruments }\end{array}$ & 85.18 & 85.18 & 85.18 & 85.18 \\
\hline Sargan test (p-value) & 0.25 & 0.65 & 0.22 & 0.58 \\
\hline
\end{tabular}

Note: Sample period is 3 years before and after M\&A (excluding M\&A year) for M\&A banks and all years for never M\&A ban Standard errors in brackets below each coefficient estimate. *, **, ***, indicate statistical significance at the 10, 5 and 1 percent level respectively. All the specifications include Never M\&A dummy, Target dummy, size dummies and a constant. Bank size is defined as follows: small: bank size less than 1 trillion yen; medium: 1-10 trillion yen; large: 10-55 trillion yen; mega: more than 55 trillion yen (measured by total assets deflated with 2000 price). Bank sub-samples are based on post-merger size. Time fixed effects included in efficiency estimation.3.3 Do 


\section{Bank Mergers Lead Managers to Pursue "The Sweet Life"?}

To complete this exploration of the channel through which bank mergers affect efficiency, we next examine whether the relationship between the Lerner Index measure of market power and efficiency changes after an M\&A event. Specifically, we run a reduced form specification as in equation (6), in which market power - "Lerner" - is interacted with a "After M\&A" dummy:

$$
\begin{aligned}
\text { efficiency }_{i, t}= & \beta_{0}^{Q L}++\beta_{1}^{Q L} \text { NeverM\&A } A_{i}+\beta_{2}^{Q L} \text { Target }_{i, t}+\beta_{3}^{Q L}{\text { AfterM } \& A_{i, t}+\beta_{4}^{Q L} \text { Lerner }_{i, t}} \\
& +\beta_{5}^{Q L} \text { AfterM\&A } \cdot \text { Lerner }_{i, t}+\sum_{k=2}^{4} \delta_{k}^{Q L} \operatorname{Size}_{i, t}^{k}+\varepsilon_{i, t}^{Q L}
\end{aligned}
$$

The results, reported in columns 1-2 of Table 3, indicate that more market power, as indicated by the Lerner Index, is still associated with higher profit efficiency, but the effect of market power on profit efficiency weakens, and in fact becomes negative for large and mega banks, after merger.

Table 3. The relationship between market power and efficiency for large and mega banks

\begin{tabular}{|c|c|c|c|c|}
\hline & Profit efficiency & $\begin{array}{l}\text { Rank profit } \\
\text { efficiency }\end{array}$ & Cost efficiency & Rank cost efficiency \\
\hline \multirow{2}{*}{$\begin{array}{l}\text { Lerner Index } \\
\text { After M\&A }\end{array}$} & $-3.44^{*}$ & $-7.15^{*}$ & 1.98 & 6.58 \\
\hline & {$[1.811]$} & [4.117] & {$[1.373]$} & [4.347] \\
\hline \multirow[t]{2}{*}{ Lerner Index } & $0.25 * * *$ & $0.28 *$ & 0.02 & -0.17 \\
\hline & {$[0.064]$} & {$[0.145]$} & {$[0.048]$} & {$[0.153]$} \\
\hline \multirow[t]{2}{*}{ After M\&A } & $2.21 * *$ & $4.61^{*}$ & -1.24 & -3.99 \\
\hline & [1.100] & [2.500] & [0.834] & [2.639] \\
\hline \multirow[t]{2}{*}{ Never M\&A } & $-0.12 * * *$ & $-0.16^{*}$ & 0.04 & $0.18 * *$ \\
\hline & {$[0.037]$} & {$[0.083]$} & {$[0.028]$} & {$[0.088]$} \\
\hline \multirow[t]{2}{*}{ Target } & $-0.14 * * *$ & $-0.22 * *$ & 0.03 & $0.17 *$ \\
\hline & {$[0.038]$} & {$[0.087]$} & [0.029] & {$[0.092]$} \\
\hline \multirow[t]{2}{*}{ Mega } & $-0.21 * * *$ & $-0.30 * * *$ & 0.03 & $0.20 * *$ \\
\hline & {$[0.042]$} & {$[0.095]$} & {$[0.032]$} & {$[0.100]$} \\
\hline \multirow[t]{2}{*}{ Large } & $-0.06 * * *$ & -0.06 & -0.02 & -0.01 \\
\hline & {$[0.020]$} & {$[0.046]$} & {$[0.015]$} & [0.049] \\
\hline \multirow[t]{2}{*}{ Small } & $0.04 * * *$ & $0.07 * * *$ & 0.00 & -0.00 \\
\hline & {$[0.008]$} & {$[0.018]$} & {$[0.006]$} & [0.019] \\
\hline \multirow[t]{2}{*}{ Constant } & $0.74 * * *$ & $0.53 * * *$ & $0.78 * * *$ & $0.42^{* * *}$ \\
\hline & {$[0.039]$} & {$[0.090]$} & {$[0.030]$} & {$[0.095]$} \\
\hline Observations & 1,286 & 1,286 & 1,286 & 1,286 \\
\hline Number of banks & 133 & 133 & 133 & 133 \\
\hline Number of years & 12 & 12 & 12 & 12 \\
\hline $\begin{array}{l}\text { F statistic for } \\
\text { instruments }\end{array}$ & 23.43 & 23.43 & 23.43 & 23.43 \\
\hline Sargan test ( $p$-value) & 0.32 & 0.60 & 0.22 & 0.31 \\
\hline
\end{tabular}
- 2SLS-IV Instrumental Variable Regression

Note: Sample period is 3 years before and after M\&A (excluding M\&A year) for M\&A banks and all years for never M\&A ban Standard errors in brackets below each coefficient estimate. $*, * *, * *$, indicate statistical significance at the 10, 5 and 1 percent level respectively. All the specifications include Never M\&A dummy, Target dummy, size dummies and a constant. Bank size is defined as follows: small: bank size less than 1 trillion yen; medium: 1-10 trillion yen; large: 10-55 trillion yen; mega: more than 55 trillion yen (measured by total assets deflated with 2000 price). Bank sub-samples are based on post-merger size. Time fixed effects included in efficiency estimation. 
Figure 3 illustrates graphically this main result. Before merger, the relationship between market power and profit efficiency is slightly positive, with a slope of 0.25 : this indicates that a $1 \%$ increase in market power increases profit efficiency by $0.25 \%$. After a merger event, however, the relationship between market power and profit efficiency changes dramatically and becomes negative, with a slope of -3.19. This implies that after a bank merger, bank managers are on average enjoying "the sweet life": a $1 \%$ increase in market power leads to a $3.19 \%$ decline in profit efficiency.

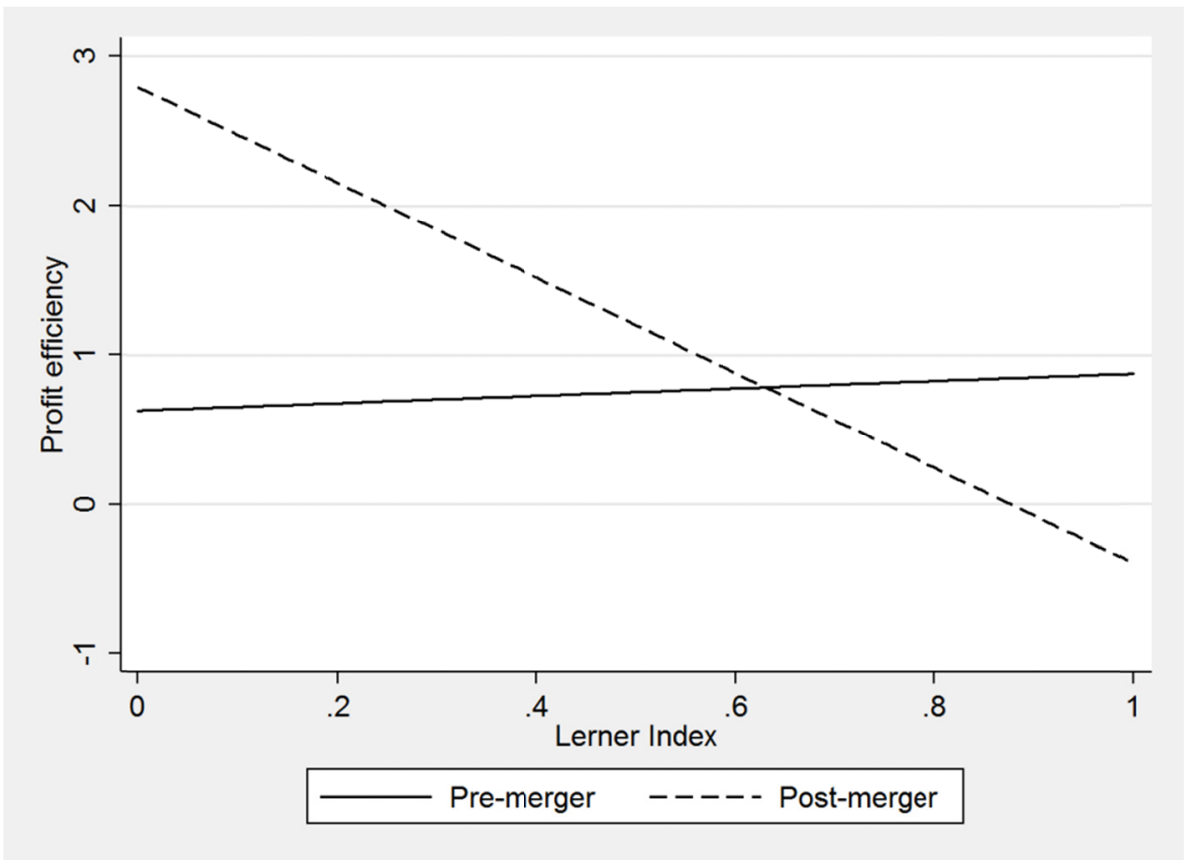

Figure 3. The relationship between market power and profit efficiency after M\&A - large and mega banks

\section{Discussion}

The results above present evidence that managers of merged large and mega banks take advantage of their increased market power to pursue la dolche vita or "the sweet life" instead of continuing to push for increases in profit efficiency and, by implication, higher monopoly rents. First, we confirmed that for large and mega banks, merger conveys significant increases in market power. Secondly, on average, higher market power is associated with higher profit efficiency. In other words, bank managers on average are not pursuing "the sweet life". On the contrary, those with higher market power tend to be more profit efficient, presumably with the aim of reaping higher monopoly profits.

However, the relationship between market power and profit efficiency changes and becomes statistically significantly negative after large or mega banks merge. These results are robust to two-stage least-squares instrumental variable estimation, which addresses potential simultaneity bias between market power and profit efficiency. After merger, managers of large or mega banks choose to operate inefficiently rather than pursue further profit efficiency. Merger seems to shift bank manager incentives toward "the sweet life"; what Hicks (1935) referred to as "the best of all monopoly profits".

\section{Acknowledgements}

This work was supported by JSPS KAKENHI Grant Number 26380398.

\section{References}

Arellano, M., \& Bond, S. (1991). Some Tests of Specification for Panel Data: Monte Carlo Evidence and an Application to Employment Equations. Review of Economic Studies, 58(2), 277-97.

Bertrand, M., \& Mullainathan, S. (2003). Enjoying the Quiet Life? Corporate Governance and Managerial Preferences. Journal of Political Economy, 111(5), 1043-1075. http://doi.org/10.1086/376950 
Blundell, R., \& Bond, S. (1998). Initial conditions and moment restrictions in dynamic panel data models. Journal of Econometrics, 87(1), 115-143. http://doi.org/10.1016/S0304-4076(98)00009-8

Hicks, J. R. (1935). Annual Survey of Economic Theory: The Theory of Monopoly. Econometrica, 3(1), 1-20.

Ito, T. (2001, December 7). Kinyu Tougou, kibo yori rieki, keiei shuhou no sasshin wo [Consolidation of financial institutions: emphasize profitability over size, focus on reform of management, in Japanese]. Nihon Keizai Shimbun, p. 29.

Koetter, M., Kolari, J. W., \& Spierdijk, L. (2012). Enjoying the Quiet Life under Deregulation? Evidence from Adjusted Lerner Indices for U.S. Banks. Review of Economics and Statistics, 94(2), 462-480. http://doi.org/10.1162/REST_a_00155

Montgomery, H., Harimaya, K., \& Takahashi, Y. (2014). Too big to succeed? Banking sector consolidation and efficiency. Journal of International Financial Markets, Institutions and Money, 32, 86-106. http://doi.org/10.1016/j.intfin.2014.05.005

Nihon Keizai Shimbun. (2002, April 3). Mizuho gin no ATM shougai, sankou shudouken arasoi mo hibiku [Mizuho Bank's ATM failure may have been partly due to rivalry among the three merged banks]. Nihon Keizai Shimbun, p. 7.

Yamori, N., \& Harimaya, K. (2009). Mergers decision in Japanese small mutual banks: Efficiency improvement or empire buildings? Corporate Ownership and Control, 7(2), 117-125.

Yamori, N., \& Harimaya, K. (2010). Do Managers of Mutual Institutions Choose Efficiency-Improving Mergers? The Recent Experience of Japanese Credit Associations. The IUP Journal of Bank Management, IX(1 \& 2), 7-11.

\section{Notes}

Note 1. See, for example, Montgomery, Harimaya, and Takahashi (2014). Earlier studies by Yamori and Harimaya $(2009,2010)$ found that mergers by small credit associations or mutual banks in Japan also result in lower technical and cost efficiency just after merger, but that efficiency was restored within a few years.

Note 2. Our sample does not include Japan Post, since it is not a private bank, and a few Japanese Bankers Association member banks that are substantially different from other members: the Norinchukin Bank, Orix Trust \& Banking, Nomura Trust and Banking, Seven Bank and Citibank Japan. 